\title{
Effect of Different Dietary Protein Levels on Physio-metabolic Response during Stunting of Milkfish, Chanos chanos (Forsskal, 1775) Reared under Pond Conditions
}

\author{
Mamidala Shyam Prasad ${ }^{1,2}$, Muralidhar P. Ande ${ }^{1}$, Karthireddy Syamala1, \\ Narinder Kumar Chadha², Paramita Banerjee Sawant², Biji Xavier ${ }^{3}$, P. Gireesh-Babu ${ }^{4}$
}

10.18805/IJAR.B-4813

\begin{abstract}
Background: Stunting is a process of suppressing growth from unfavourable conditions. The protein supplementation during stunting gives scope to maintain the nutrient reserves of fish and its quality.

Methods: A feeding trial was conducted for eight months to study the effect of three hetero-nitrogenous diets with $25 \%$ (control), $30 \%$ (T1) and 35\% (T2) crude protein (CP) levels on growth and physio-metabolic responses of Chanos chanos fingerlings during stunting. Milk fish fingerlings with a mean body weight of $11.71 \pm 0.18 \mathrm{~g}$ were stocked in earthen ponds @ $20 \mathrm{no} / \mathrm{m}^{2}$ in each replicate $(\mathrm{n}=3)$ was fed @ $2 \%$ biomass throughout the experiment.

Result: Fish fed with T1 diet showed better specific growth rate $\left(0.64 \pm 0.01 \% \mathrm{~d}^{-1}\right)$, weight gain percentage $(362.56 \pm 14.95)$ and protease activity $(7.53 \pm 0.25 \mathrm{U} / \mathrm{mg}$ protein). Whereas, lower activity was observed for the enzyme assay, namely superoxide dismutase (45.41 \pm 2.50 $\mathrm{U} / \mathrm{min} / \mathrm{mg}$ protein), aspartate aminotransferase $(34.01 \pm 1.88 \mathrm{U} / \mathrm{min} / \mathrm{mg}$ protein) and alanine aminotransferase $(39.64 \pm 0.64 \mathrm{U} / \mathrm{min} / \mathrm{mg}$ protein). Hence, it may be concluded that the dietary protein inclusion level of $30 \% \mathrm{CP}$ showed better growth performance and lower physio-metabolic response in milkfish fingerlings during the stunting.
\end{abstract}

Key words: Chanos chanos, Dietary protein, Growth, Physio-metabolic responses, Stunting.

\section{INTRODUCTION}

Milkfish is suitable candidate species for intensive brackishwater farming (CIBA, 2018). Despite the progress made in the induced breeding of milkfish, seed demand is fulfilled through the wild collection (CIBA annual report, 2015). Stunting is the production of dwarf and quality individuals from unfavourable environmental conditions like high stocking density and limited food availability, which leads to utilization of stored nutrition such as lipid and protein and thus affecting growth (Ferki et al., 2018; Klinger et al., 1983) to get year-round availability (Sahoo et al., 2021). In milkfish, an eight-month stunting period with $20 \mathrm{no} / \mathrm{m}^{2}$ stocking density has been reported to be sufficient to obtain optimum compensatory growth under grow-out culture conditions when fed with de-oiled rice bran (Lingam et al., 2018).

However, stunting is assumed to deplete the nutritional quality of fish (Yeannes and Almondes, 2003). This in turn affects energy levels, metabolic activity in stunted fingerling due to limited nutrient availability (Ferki et al., 2018). Hence, nutrient supplementation during stunting is essential to maintain the quality of fingerlings by reducing the stress response (Khalil et al., 2015). Protein is one of the crucial components of feed that greatly influences fingerlings' growth rate and quality (Surjobala et al., 2021). Protein requirement for different life stages of milkfish such as fry, fingerling/adult and broodstock was reported to be $40 \%$, 24$36 \%$ and $36 \%$, respectively, under intensive farming (CIBA, 2018). Protein supplementation may compensate for the loss of stored nutrients in the fish body and mitigate the stress
'ICAR-Central Institute of Fisheries Education, Brackishwater Fish Farm, Kakinada Regional Centre, Kakinada-533 007, Andhra Pradesh, India.

2ICAR-Central Institute of Fisheries Education, Mumbai-400 061, Maharashtra, India.

${ }^{3}$ ICAR-Central Marine Fisheries Research Institute, Visakhapatnam530 003, Andhra Pradesh, India.

${ }^{4}$ ICAR-National Research Centre on Meat, Hyderabad-500 092, Telangana, India.

Corresponding Author: Muralidhar P. Ande, ICAR-Central Institute of Fisheries Education, Brackishwater Fish Farm, Kakinada Regional Centre, Kakinada-533 007, Andhra Pradesh, India. Email: murali@cife.edu.in

How to cite this article: Prasad, M.S., Ande, M.P., Syamala, K., Chadha, N.K., Sawant, P.B., Xavier, B. and Gireesh-Babu, P. (2021). Effect of Different Dietary Protein Levels on Physio-metabolic Response during Stunting of Milkfish, Chanos chanos (Forsskal, 1775) Reared under Pond Conditions. Indian Journal of Animal Research. DOI: 10.18805/IJAR.B-4813.

Submitted: 26-10-2021 Accepted: 21-12-2021 Online: 27-12-2021

during stunting (Ferki et al., 2018). Although protein-rich feeds are reported to improve the quality of fingerlings during stunting, the excessive dietary protein metabolized as an energy source may result in increased nitrogen discharge due to de-amination (Pascual et al., 2003; Babaei et al., 2016).

Hence, it is imperative to determine the optimum dietary protein inclusion levels and their effect during stunting to 
Effect of Different Dietary Protein Levels on Physio-metabolic Response during Stunting of Milkfish, Chanos chanos...

preserve fingerling quality with minimum stress. Therefore, the present study was carried out to determine the optimum protein inclusion level by examining the digestive enzyme activity, growth and physio-metabolic response.

\section{MATERIALS AND METHODS Experimental setup and diet}

The experiment was conducted in 2020 (March to October) in the earthen ponds at BWFF, ICAR-CIFE, Kakinada Regional Centre, Andhra Pradesh. Uniform weight $(11.71 \pm 0.18 \mathrm{~g})$ of pond reared milkfish fingerlings were stocked in 0.02 ha ponds @ 20 no $/ \mathrm{m}^{2}$ (Lingam et al., 2018) in each replicate. The experiment comprised three groups that indicated hetero-nitrogenous diets, including control [C; $25 \%$ crude protein (CP)], Treatment group $1(\mathrm{~T} 1 ; 30 \% \mathrm{CP})$ and Treatment group 2 (T2; 35\% CP) (Table 1). The experimental diets were formulated and prepared by following De Silva and Anderson's standard methods (1995). The experiment was conducted in triplicate by following the completely randomized design.

\section{Sample collection and preparation}

Milkfish fingerlings $(n=40)$ from each replicate were sampled (at 30 days intervals) to record growth data and released back into the respective replicate group. For enzyme assay,

Table 1: Ingredients and proximate composition of the experimental diets.

\begin{tabular}{llll}
\hline \multirow{2}{*}{ Ingredients $^{*}$} & \multicolumn{3}{c}{ Experiments diets } \\
\cline { 2 - 4 } & $\mathrm{C}$ & $\mathrm{T} 1$ & $\mathrm{~T} 2$ \\
\hline
\end{tabular}

\begin{tabular}{|c|c|c|c|}
\hline \multicolumn{4}{|c|}{$\begin{array}{l}\text { Ingredients composition of } \\
\text { the diet ( } \% \text { dry matter basis) }\end{array}$} \\
\hline Fish meal & 17.00 & 18.00 & 16.00 \\
\hline Soybean meal & 18.00 & 25.87 & 25.87 \\
\hline Groundnut oil cake & 4.00 & 9.50 & 28.00 \\
\hline Wheat flour & 12.00 & 8.00 & 8.00 \\
\hline De-oiled ricebran & 13.87 & 11.50 & 8.00 \\
\hline Cornflour & 19.00 & 11.00 & 1.00 \\
\hline Tapioca flour & 8.00 & 8.00 & 5.00 \\
\hline Fish oil & 3.00 & 3.00 & 3.00 \\
\hline Vegetables oil & 3.00 & 3.00 & 3.00 \\
\hline Vit-Min mixturre & 2.00 & 2.00 & 2.00 \\
\hline Choline chloride & 0.10 & 0.10 & 0.10 \\
\hline Butylated hydroxytolene & 0.03 & 0.03 & 0.03 \\
\hline \multicolumn{4}{|c|}{$\begin{array}{l}\text { Proximate composition of } \\
\text { the feed ( } \% \text { dry matter basis) }\end{array}$} \\
\hline Crude protein & 25.00 & 30.00 & 35.00 \\
\hline Ether extract & 8.62 & 8.77 & 9.15 \\
\hline Crude fiber & 2.98 & 3.11 & 3.65 \\
\hline Nitrogen free extract & 54.37 & 48.32 & 42.24 \\
\hline Total ash & 9.03 & 9.80 & 9.96 \\
\hline Gross energy (Kcal/g) & 4.44 & 4.51 & 4.62 \\
\hline
\end{tabular}

\# All the ingredients were procured from the local market of Kakinada, Andhra Pradesh, India. liver and intestine tissue samples $(n=3)$ were collected (at 60 days intervals) in chilled $0.25 \mathrm{M}$ sucrose and prepared $5 \%$ tissue homogenate for analysis (Kumar and Tembre 1998).

\section{Growth parameters}

Growth performance of the fish calculated as follows:

Weight gain $(W G)=$ Final weight $(F W)$ - Initial weight (IW)

$W G(\%)=\frac{F W-I W}{I W} \times 100$

Specific growth rate $\left(S G R \% d^{-1}\right)=\frac{\log _{e} F W-\log _{e} I W}{\text { Days of culture }} \times 100$

Feed conversion ratio $(F C R)=\frac{\text { Feed intake }}{\text { Net weight gain }} \times 100$

Protein efficiency ratio $(P E R)=\frac{\text { Net weight gain }}{\text { Protein fed }} \times 100$

Survival rate $(\%)=\frac{\text { Total no. of fish harvested }}{\text { Total no. of fish stocked }} \times 100$

\section{Biochemical analysis}

Intestinal protease activity was determined by the casein digestion method (Drapeau, 1974). Amylase activity was assayed with $2 \%(\mathrm{w} / \mathrm{v})$ starch solution as substrate (Rick and Stegbauer, 1974) and lipase activity was estimated by the titrimetric method of Cherry and Crandell (1932).

Superoxide dismutase (SOD) was assayed based on the oxidation of epinephrine-adrenochrome transition (Misra and Frodovich, 1972). Catalase (CAT) was assayed according to the method described by Takahara et al. (1960). Aspartate aminotransferase (AST) and Alanine aminotransferase (ALT) activity were estimated as described by Wooton (1964).

\section{Statistical analysis}

Statistical analysis was performed SPSS version 25.0 using one-way analysis of variance to test the significant difference among the treatments. Comparison of the means was demonstrated by Duncan's multiple range tests.

\section{RESULTS AND DISCUSSION \\ Growth performance and survival}

Dietary CP level significantly affected the growth performance of milkfish fingerlings during the stunting period (Table 2). Significantly higher WG (Fig 1), WG\%, feed intake, protein intake, SGR and PER were also recorded in the T1 group (30\% CP). The least WG\% observed in the T2 group (35\% CP) could be attributed to the limited acceptanceof a high protein diet by fish during starvation. Previous studies on other fish species Siberian sturgeon, Acipenser baerii (Babaei et al., 2016) suggested that fish do not readily accept the high protein diet due to insufficient non-protein energy diet. During stunting of fingerlings, nutritional imbalance with high protein diets negatively affects growth, leading to stress, growth suppression and less survival (Kiron, 2012). It is 
Effect of Different Dietary Protein Levels on Physio-metabolic Response during Stunting of Milkfish, Chanos chanos...

speculated that the excess protein in diet undergoes deamination in the body resulting in the supply of proteinenergy for metabolism rather than body growth (Furne et al., 2008). It is also worth mentioning that feeding fish with lower protein levels leads to slower growth and poor survival (Khalil et al., 2015). The results suggest that the $30 \%$ crude protein inclusion levels were better suited for stunting compared to other protein fed groups based on the

Table 2: Growth performance of $C$. chanos fingerlings during stunting.

\begin{tabular}{lccc}
\hline Treatment & $\mathrm{C}$ & $\mathrm{T} 1$ & $\mathrm{~T} 2$ \\
\hline Initial weight $(\mathrm{g})$ & $11.97 \pm 0.12^{\mathrm{a}}$ & $11.46 \pm 0.24^{\mathrm{a}}$ & $11.70 \pm 0.18^{\mathrm{a}}$ \\
Final weight (g) & $33.70 \pm 0.15^{\mathrm{b}}$ & $52.93 \pm 0.59^{\mathrm{c}}$ & $23.33 \pm 0.06^{\mathrm{a}}$ \\
WG (g) & $21.73 \pm 0.26^{\mathrm{b}}$ & $41.47 \pm 0.83^{\mathrm{c}}$ & $11.63 \pm 0.15^{\mathrm{a}}$ \\
Feed intake (g)/fish & $113.88 \pm 0.82^{\mathrm{b}}$ & $141.50 \pm 1.18^{\mathrm{c}}$ & $89.55 \pm 0.88^{\mathrm{a}}$ \\
Protein intake (g)/fish & $28.62 \pm 0.21^{\mathrm{a}}$ & $42.86 \pm 0.36^{\mathrm{c}}$ & $31.44 \pm 0.31^{\mathrm{b}}$ \\
WG\% & $181.70 \pm 3.96^{\mathrm{b}}$ & $362.56 \pm 14.95^{\mathrm{c}}$ & $99.45 \pm 2.76^{\mathrm{a}}$ \\
SGR(\%d-1) & $0.43 \pm 0.01^{\mathrm{b}}$ & $0.64 \pm 0.01^{\mathrm{c}}$ & $0.29 \pm 0.02^{\mathrm{a}}$ \\
FCR & $5.24 \pm 0.03^{\mathrm{b}}$ & $3.41 \pm 0.10^{\mathrm{a}}$ & $7.71 \pm 0.17^{\mathrm{c}}$ \\
PER & $0.76 \pm 0.01^{\mathrm{b}}$ & $0.95 \pm 0.01^{\mathrm{c}}$ & $0.37 \pm 0.02^{\mathrm{a}}$ \\
ANPU & $15.81 \pm 0.82^{\mathrm{b}}$ & $15.05 \pm 0.47^{\mathrm{b}}$ & $10.46 \pm 0.73^{\mathrm{a}}$ \\
Survival (\%) & $90.50 \pm 0.50^{\mathrm{ab}}$ & $94.50 \pm 0.50^{\mathrm{b}}$ & $86.50 \pm 0.50^{\mathrm{a}}$
\end{tabular}

All values are expressed as mean $\pm S E$; mean values in the same column with different superscripts differ significantly $(P<0.05)$. observed parameters i.e., weight gain, SGR, feed intake, WG\%, ANPU, FCR and PER .

\section{Digestive enzyme assay}

Protease, amylase and lipase activities of stunted milkfish fingerlings were significantly affected $(P<0.05)$ in the treatment groups and confirmed the response of digestive enzymes against dietary protein levels (Kumar et al., 2019). T1 group showed higher protease activity during the entire experimental period (Fig 2a) with a value of $7.53 \pm 0.25 \mathrm{U} /$ $\mathrm{mg}$ protein at the end of the experiment. The protease enzyme plays a crucial role in activating and stimulating the reactions related to the mobilization of energy through the metabolic pathways, resulting in variation in growth (Furne et al., 2008). It also indicates that the difference in potential feed utilization results in the efficient uptake of protein for better growth performance (Babaei et al., 2016). Lower protease activity in the high protein supplemented group (35\% CP) suggests that the capacity to digest a high amount of proteins is compromised due to feeding deprivation and stress. In this respect, Abolfathi et al. (2012), observed lower protease activity in juvenile Caspian roach, Rutilus rutilus caspicus, with a high protein diet.

Amylase activity showed a decreased trend with an increase in protein level (Fig 2b). The highest amylase activity $(4.68 \pm 0.10 \mathrm{U} / \mathrm{mg}$ protein) was recorded in the control

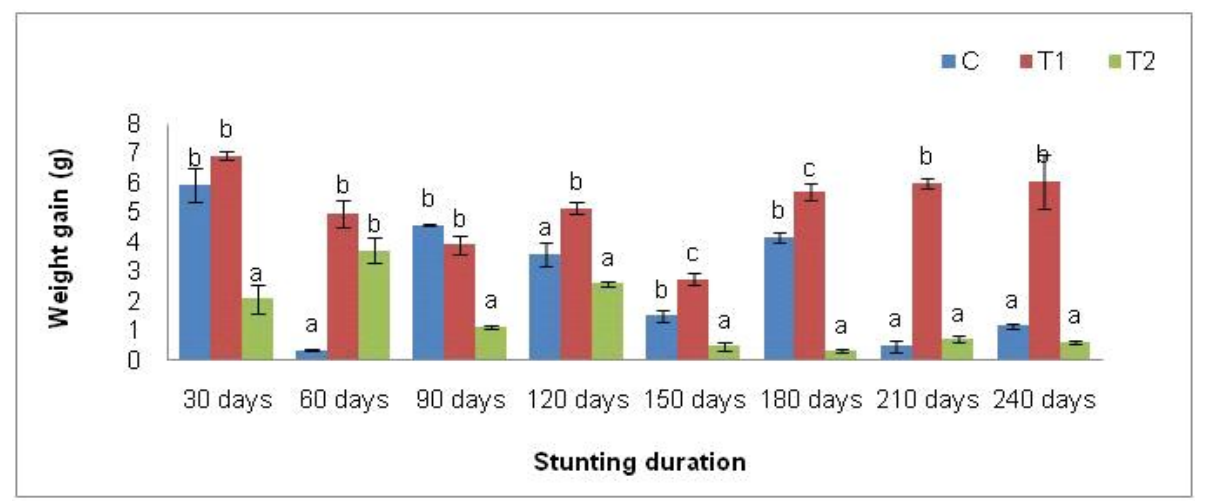

Fig 1: Average weight gain $(\mathrm{g})$ of $C$. chanos fingerlings during stunting.

Data is presented as mean $\pm S E$ and superscripts are significantly different $(P<0.05)$.

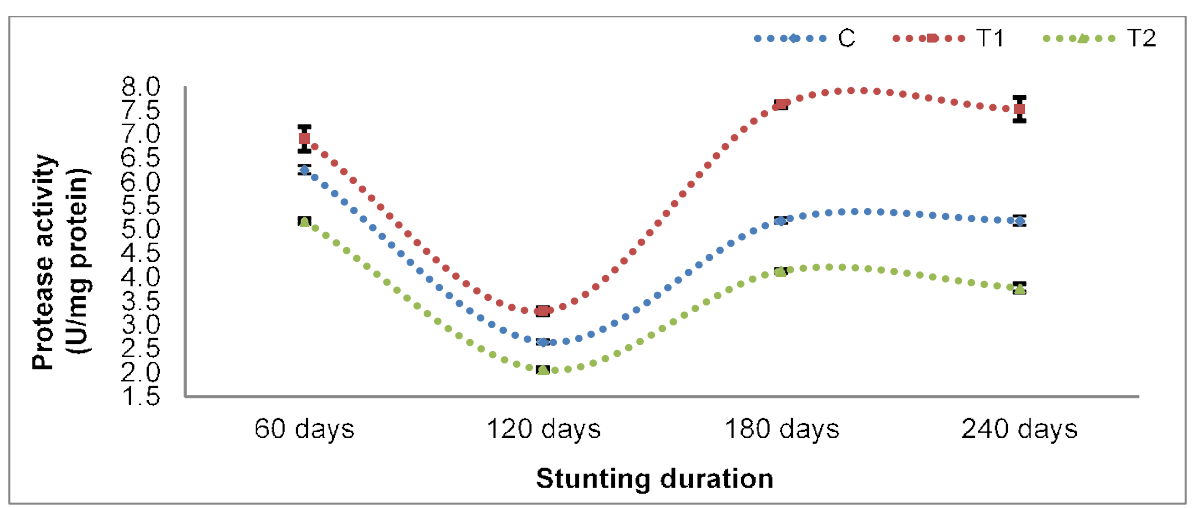

Fig 2a: Protease activity (U/mg protein) of stunted $C$. chanos fingerlings.

Data is presented as mean \pm SE with a significant difference $(P<0.05)$. 
Effect of Different Dietary Protein Levels on Physio-metabolic Response during Stunting of Milkfish, Chanos chanos...

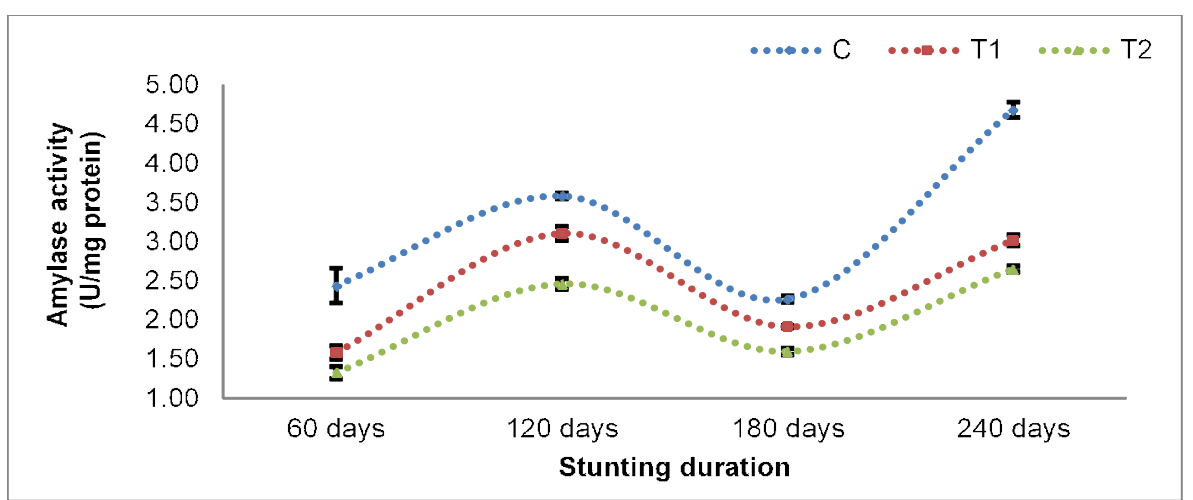

Fig 2b: Amylase activity (U/mg protein) of stunted C.chanos fingerlings.

Data is presented as mean \pm SE with a significant difference $(P<0.05)$.

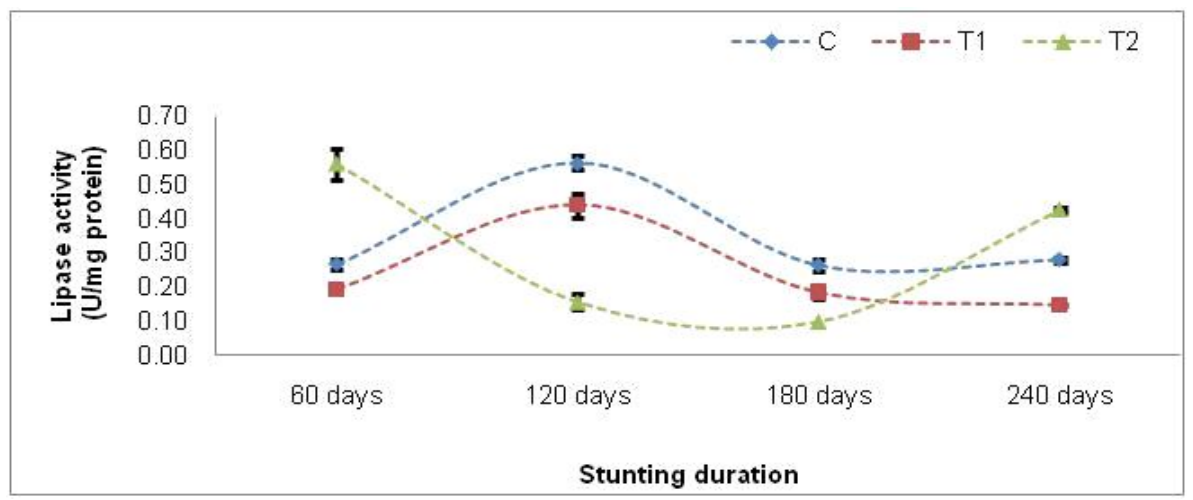

Fig 2c: Lipase activity (U/mg protein) of stunted C.chanos fingerlings.

Data is presented as mean \pm SE with a significant difference $(P<0.05)$.

group at the end of the experimental period (240 days). The lower amylase activity observed at a higher dietary protein level $(35 \% \mathrm{CP})$ could be due to degeneration of pancreatic tissue (Abolfathi et al., 2012) and intestinal mucosal cell damage during food deprivation (Kumar and Tembre, 1998).

In silver barb, Puntius gonionotus (Mohanta et al., 2008) and rohu, Labeo rohita (Mohapatra et al., 2003), it is reported that the liver and alimentary tract are depleted during starvation leading to a possible reduction in digestive efficiency due to decreased digestive enzyme secretion.

In the control and T1 groups, the lipase activity increased until 120 days and gradually decreased later (Fig 2c). The higher lipase activity observed in the $35 \% \mathrm{CP}$ group could be attributed to the possible influence of dietary protein on the pancreatic lipase secretions to hydrolyze the triglycerides during digestion. Similar reports were also made Adriatic sturgeon, Acipenser naccerii and rainbow trout, Oncorhynchus mykiss (Furne et al., 2008).

\section{Anti-oxidant enzyme assay}

Anti-oxidants and specialized enzymes like SOD and CAT can neutralize reactive oxygen species [ROS-includes superoxide anion, hydrogen peroxide and hydroxyl radicals] generated through metabolic activity (Rahman, 2007). The highest SOD and CAT activities were observed in T2 and T1 groups, respectively.
The superoxide dismutase (SOD) activity of milkfish fingerlings was significantly affected with varying dietary protein levels $(P<0.05)$ during stunting. The liver displayed fluctuation in the SOD activity across the variables. While the 120 and 240 days sampling points recorded the highest SOD activity, the 60 and 140 days sampling points showed the lowest activity (Fig 3 ). The higher SOD activity recorded in the T2 group could be due to the increased production of free radicals because ofthe physiological imbalance between the level of anti-oxidants and oxidants during oxidative stress with a high protein diet (Pascual et al., 2003). Research reports on yellow croaker, Pseudosciaena crocea (Zhang et al., 2008) and Siberian sturgeon, A. baerii (Babaei et al., 2016) suggests that high protein diet is unproductive for compensating the oxidative stress during stunting.

The catalase activity was higher during the entire experimental period. At the end of the experimental period, the $\mathrm{T} 1$ group recorded the highest catalase activity in the liver $(0.23 \pm 0.001 \mathrm{U} / \mathrm{min} / \mathrm{mg}$ protein). When compared across the sampling intervals, the catalase activity was seen to be more or less stable (Fig 4). The higher CAT activity in the $30 \%$ CP group indicates sufficient enzymes to degrade hydrogen peroxide into molecular oxygen and water (Kumar et al., 2019). Similar studies on Siberian sturgeon, $A$. baerii (Babaei et al., 2016); Adriatic sturgeon, A.naccarii and rainbow trout, O.mykiss (Furne et al., 2009) indicate that prolonged 
Effect of Different Dietary Protein Levels on Physio-metabolic Response during Stunting of Milkfish, Chanos chanos...

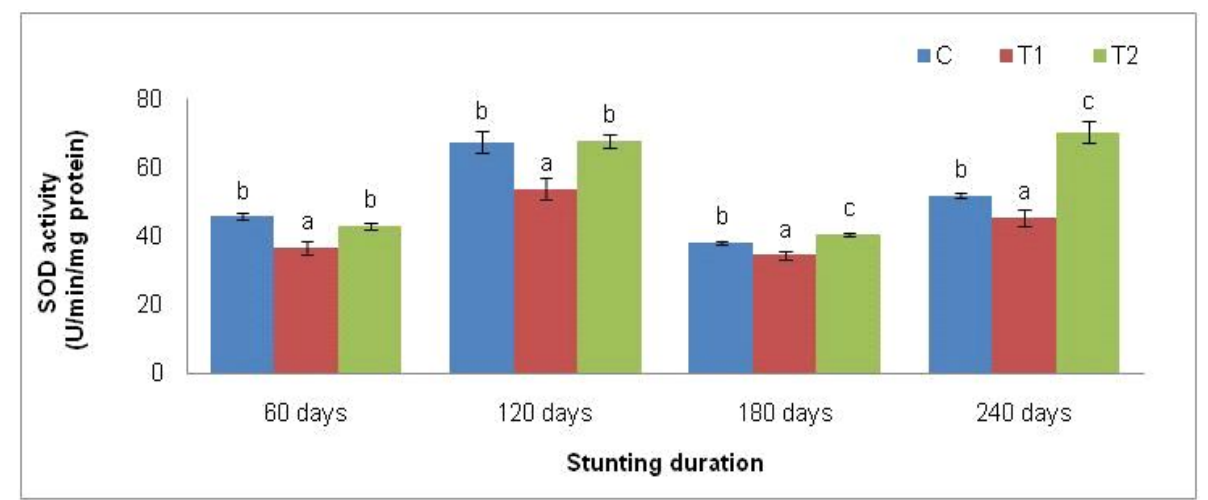

Fig 3: SOD activity (U/min/mg protein) in liver tissue of $C$. chanos fingerlings.

Data is presented as mean \pm SEand superscripts are significantly different $(P<0.05)$.

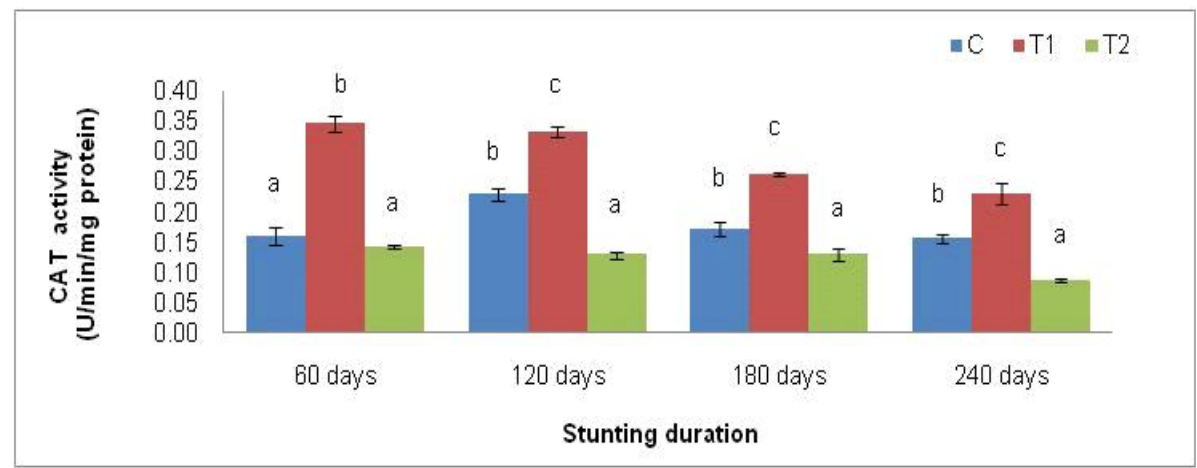

Fig 4: CAT activity $(\mathrm{U} / \mathrm{min} / \mathrm{mg}$ protein) in liver tissue of $C$. chanos fingerlings.

Data is presented as mean $\pm S E$ and superscripts are significantly different $(P<0.05)$.

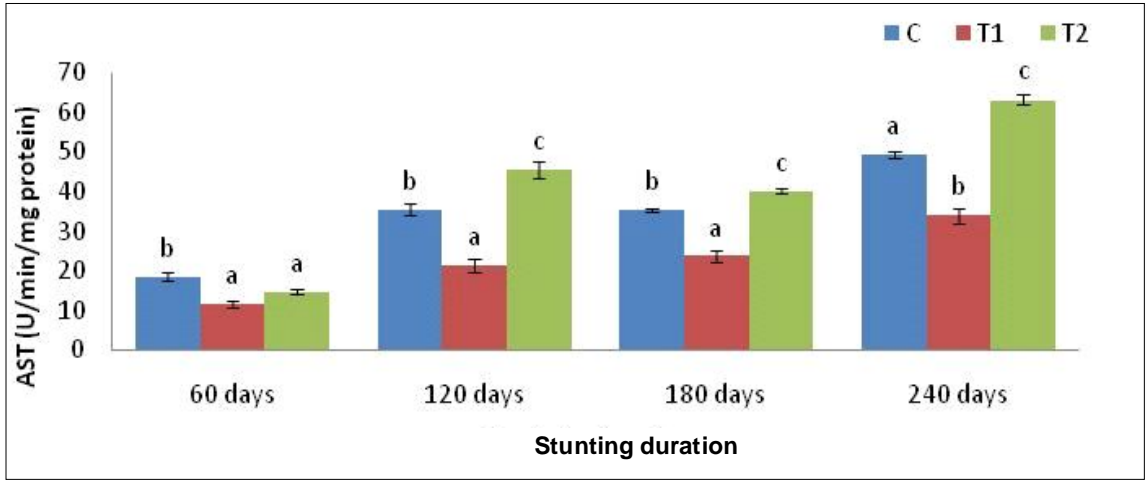

Fig 5: AST activity (U/min/mg protein) in liver tissue of $C$. chanos fingerlings.

Data is presented as mean $\pm S E$ and superscripts are significantly different $(P<0.05)$.

starvation induces a significant increase in CAT activity. SOD activity increased, while CAT activity decreased in the liver of milkfish subjected to partial deprivation in control and T2 groups. This might be due to production levels of ROS during starvation to diminish oxidative stress. Similar findings were observed in gilt-head seabream, Sparus aurata exposed to partial food deprivation (Pascual et al., 2003).

\section{Metabolic enzyme assay}

The dietary protein levels significantly $(P<0.05)$ influenced the AST and ALT activities. A steady increase in AST activity was observed across the time points tested during the stunting (Fig 5). At the end of the experimental period (240 days), the T2 group registered the highest AST activity in the liver (63.37 U/min/mg protein). Similarly, ALT activity was found to be highest in the T2 group ( $59.98 \mathrm{U} / \mathrm{min} / \mathrm{mg}$ protein) tissues (Fig 6).

The liver-specific enzymes, ALT and AST, indicate nutrient utilization of amino acids and greatly influence metabolic functions under stressful conditions for meeting the high energy demand in fish (Jiang et al., 2015; Huang et al., 2018). Increased AST and ALT enzyme activity during 


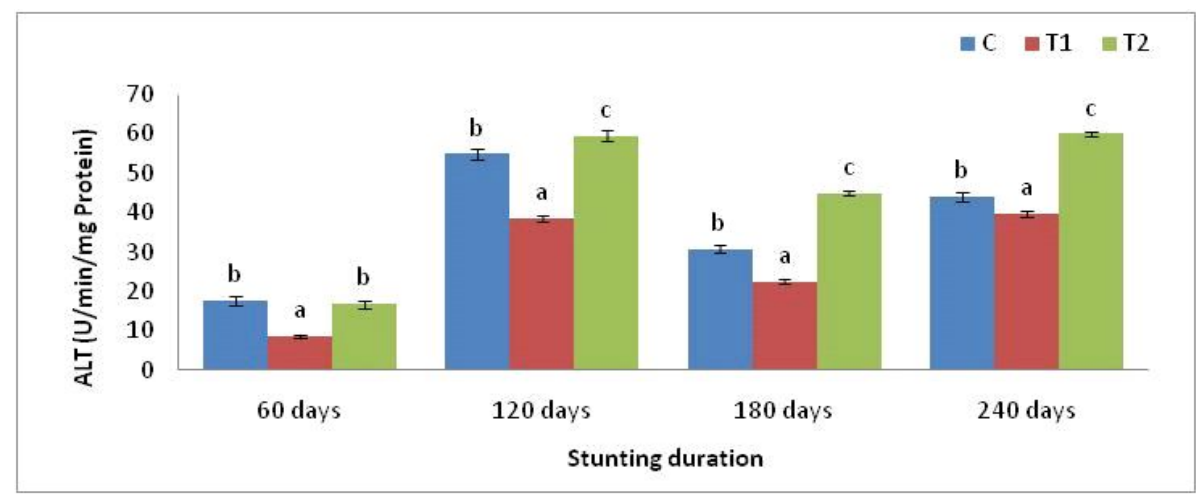

Fig 6: ALT activity (U/min/mg protein) in liver tissue of C.chanos fingerlings.

Data is presented as mean $\pm S E$ and superscripts are significantly different $(P<0.05)$.

stunting suggests that the high dietary protein forms substrates such as glycogenic aminoacids and lactates, resulting in higher gluconeogenesis under stress conditions (Perez-Jimenez et al., 2012). The AST and ALT activities were recorded minimum in the $30 \% \mathrm{CP}$ group for the entire experiment. This may be due to sufficient production of glucogenic substrates under the gluconeogenesis cycle as a protective strategy to prevent excess oxidation generated under stressful conditions (Perez-Jimenez et al., 2012). The higher activity observed in the $35 \% \mathrm{CP}$ may be attributed to the higher production of lactates to utilize the energy to meet the metabolic functions. Similarly, the ALT and AST activities increased with a high protein diet in Cyprinus carpio (Jiang et al., 2015) and L.rohita (Kumar et al., 2019).

\section{CONCLUSION}

This study concludes that the dietary protein level has a significant role in producing quality milkfish fingerlings during stunting. The $30 \%$ dietary protein levels showed better WG, WG\%, SGR, PER, higher digestive (protease activity) and metabolic enzyme activities. Fish fed with $30 \% \mathrm{CP}$ have lower SOD enzyme activity than the $25 \%$ and $35 \% \mathrm{CP}$ groups. Further, low levels of metabolic enzymes (AST and $A L T$ ) in the $30 \% \mathrm{CP}$ group indicate that the fingerlings are healthy and are of good quality. Considering all the above, the present study concludes that a $30 \%$ dietary protein level is better suited for $C$. chanos fingerlings during 8-month stunting under pond conditions.

\section{ACKNOWLEDGEMENT}

The authors would like to thank The Director and ViceChancellor of ICAR-CIFE, Mumbai, for the constant support to experiment.

\section{REFERENCES}

Abolfathi, M., Hajimoradloo, A., Ghorbani, R. and Zamani, A. (2012). Effect of starvation and refeeding on digestive enzyme activities in juvenile roach, Rutilus rutilus caspicus. Comparative Biochemistry and Physiology Part A: Molecular and Integrative Physiology. 161(2): 166-173.
Babaei, S., Abedian, K.A., Hedayati, M., Ali, M. and Isidoro Metón. (2016). Effect of diet composition on growth performance, hepatic metabolism and anti-oxidant activities in Siberian sturgeon (Acipenser baerii, Brandt, 1869) submitted to starvation and refeeding. Fish Physiology and Biochemistry. 42(6): 1509-20.

Cherry, I.S. and Crandall, J.R.L.A. (1932). The specificity of pancreatic lipase: its appearance in the blood after pancreatic injury. American Journal of Physiology. 100: 266-273.

CIBA (2015). Central Institute of Brackishwater Aquaculture. Annual Report, 8p.

CIBA (2018). A guide to milkfish Chanos chanos Aquaculture.

Drapeau, G.R. (1974). Protease from Staphyloccus aureus. Methods Enzymology. 45: 469-475.

De Silva, S.S. and Anderson, T.A. (1995). Fish Nutrition in Aquaculture. Chapman and Hall. London, UK.

Ferki, I., Putri, A.K. and Adimu, H.W. (2018). History of stunting on Anquilla species: A literature review. IOP Conf. Series: Earth and Environmental Science. 241:012-031.

Furné, M., García-Gallego, M., Hidalgo, M.C., Morales, A.E., Domezain, A., Domezain, J. and Sanz, A. (2008). Effect of starvation and refeeding on digestive enzyme activities in sturgeon (Acipenser naccarii) and rainbow trout (Oncorhynchus mykiss). Comparative Biochemistry and Physiology A. 149(4): 420-425.

Furne, M., Garcl'a-Gallego, M., Hidalgo, M.C., Morales, A.E., Domezain, A., Domezain, J. and Sanz, A. (2009). Oxidative stress parameters during starvation and refeeding periods in Adriatic sturgeon (Acipenser naccari) and rainbow trout (Oncorhynchus mykiss). Aquaculture Nutrition. 15: 587-595.

Huang, S., Yang, H., Rehman, M.U. and Tong, Z. (2018). Acute heat stress in broiler chickens and its impact on serum biochemical and electrolyte parameters. Indian Journal of Animal Research. 52(5): 683-686.

Jiang, J., Feng, L., Tang, L., Liu, Y., Jiang, W. and Zhou, X. (2015). Growth rate, body composition, digestive enzymes, transaminase activities and plasma ammonia concentration of different weight Jian carp (Cyprinus carpio var. Jian). Animal Nutrition. 1(4): 373-377. 
Effect of Different Dietary Protein Levels on Physio-metabolic Response during Stunting of Milkfish, Chanos chanos...

Khalil, A.H.M., Husseiny, E.L.W., Gattah, A.F.A. and Ghonimi A.M. (2015). Effect of feeding with different dietary protein levels and starvation on the health, nonspecific immune parameters, behavior and histoarchitectures of fantail goldfish (Carassius auratus L.). Journal of Veterinary Science and Technology. 07(01).

Kiron, V. (2012). Fish Immune System and Its Nutritional Modulation for preventive health care. Animal Feed Science and Technology. 173(1-2): 111-33.

Klinger, H., Delventhal, H. and Hilge, V. (1983). Water quality and stocking density as stressors of channel catfish (Ictalurus punctatus). Aquaculture. 30: 263-272.

Kumar, S., Sahu, N.P., Ashutosh D.D. and Ranjan, A. (2019). Feeding de-oiled rice bran based diet with varying levels of protein and lipid: Effect on physiological responses of Labeo rohita. Aquaculture. 498: 454-63.

Kumar, S. and Tembre, M. (1998). Digestive System. In: Anatomy and Physiology of Fishes. [Kumar, S., Tembre, M. (Eds.)], Chapter 6. UBS press, 56-76 pp.

Lingam, S.S., Sawant, P.B., Chadha, N.K., Pani Prasad, K., Muralidhar, A., Syamala, K. and Xavier, M. (2018). Effect of stunting on carcass quality characteristics of milkfish, Chanos chanos (Forsskal, 1775), reared under pond conditions. Aquaculture Research. 49(11): 3491-97.

Misra, H.P. and Frodovich, I. (1972). The role of superoxide anion in auto oxidation of epinephrine and a simple assay for SOD. Journal of Biological Chemistry. 247: 3179-3175.

Mohanta, K.N., Mohanty, S.N., Jena, J.K. and Sahu, N.P. (2008). Protein requirement of silverbarb, Puntius gonionotus fingerlings. Aquaculture Nutrition. 14(2): 143-152.

Mohapatra, M., Sahu, N. P. and Chaudhari, A. (2003). Utilization of gelatinized carbohydrate in diets of Labeo rohita fry. Aquaculture Nutrition. 9(3): 189-196.

Pascual, P., Pedrajas, J.R., Toribio, F., López-Barea, J. and Peinado, J. (2003). Effect of food deprivation on oxidative stress biomarkers in fish (Sparus aurata). Chemico-Biological Interactions. 145: 191-199.
Pérez-Jiménez, A., Cardenete, G., Hidalgo, M. C., García-Alcázar, A., Abellán, E. and Morales, A.E. (2012). Metabolic adjustments of Dentex dentex to prolonged starvation and refeeding. Fish Physiology and Biochemistry. 38: 1145-1157.

Rick, W. and Stegbauer, H.P. (1974). a- Amylase Measurement of Reducing Groups. In: Methods of Enzymatic Analysis. [Bergmeyer, H.U. (Ed.)]. $2^{\text {nd }}$ edn. Verlag Chemie, Weinheim, 2: $885-915 \mathrm{pp}$.

Rahman, K. (2007). Studies on free radicals, anti-oxidants and cofactors. Clinical Intervention in Aging. 2: 219.

Sahoo, P.R., Das, P.C., Nanda, S., Mohanta, K.N. and Sahu, B. (2021). Influence of photoperiod and rearing density of fry in production of stunted fingerlings of Catla catla (Hamilton). Indian Journal of Animal Research. 55(4): 479-485.

Surjobala, N., Mandal, S.C., Patel, A.B., Parhi, J. and Pandey, P.K. (2021). Effect of graded protein levels on the growth, survival and body composition of juvenile Osteobrama belangeri using semi purified diet. Indian Journal of Animal Research. 55(7): 810-817.

Takhara, S., Hamilton, H.B., Neel, J.V., Kobara, T.Y., Ogura, Y. and Nishimura, E.T. (1960). Hypocatalasemia, a new genetic carrier state. Journal of Clinical Investigation. 39 : 610-619.

Wooten, I.D.P. (1964). Microanalysis. In: Medical Biochemistry, [Churchill, J., Churchill, A. (Eds.)], $4^{\text {th }}$ ed. London. pp. 101-107.

Yeannes, M.I. and Almandos, M.E. (2003). Estimation of fish proximate composition starting from water content. Journal of Food Composition and Analysis. 16(1): 81-92.

Zhang, X.D., Zhu, Y.F., Cai, L.S. and Wu, T.X. (2008). Effects of fasting on the meat quality and anti-oxidant defenses of market-size farmed large yellow croaker (Pseudosciaena crocea). Aquaculture. 280(1-4): 136-39. 